\title{
Omani Undergraduate Students' Awareness and Experiences of the Research-Teaching Nexus
}

\author{
Mohammed Abdullah Al-Nofli ${ }^{1}$ \\ ${ }^{1}$ Faculty of Education and Arts, Sohar University, Sohar, Sultanate of Oman \\ Correspondence: Mohammed A. Al-Nofli, Faculty of Education and Arts, Sohar University, Sohar, Sultanate of \\ Oman.
}

Received: January 15, 2021

Accepted: March 9, 2021

Online Published: March 10, 2021

doi:10.5430/ijhe.v10n4p207

URL: https://doi.org/10.5430/ijhe.v10n4p207

\begin{abstract}
The research-teaching nexus is an important factor in the enhancement of the quality of teaching and learning in higher education institutions. The purpose of the study was to explore undergraduate students' awareness and experiences of research in one faculty at Sohar University, Oman. Data were gathered from 240 undergraduate students using an online survey. Overall, results indicated that while there was good evidence of students' awareness and experiences of research, less than half of the students in the sample were aware of or had experienced important research activities. Some students reported advantages arising from their participation in research-including developing research skills and gaining new knowledge. They also reported the need for more hands-on research experience and instructor support. Some findings were generally consistent with the literature on students' awareness and experiences of research. The study provided important implications for the research-teaching nexus at Sohar University.
\end{abstract}

Keywords: research-teaching nexus, undergraduate students, research awareness, research experience, Oman

\section{Introduction}

For several decades, the link between research and teaching has been a topic of international interest in higher education institutions. Many institutions and researchers have increasingly used the research-teaching nexus (RTN) as a means to enhance the quality of university teaching. Healey and Jenkins (2009) argued that undergraduate students face what appears to be an uncertain future. Helping them "understand and cope with uncertainty, ambiguity, complexity, and change is not just valuable to their development at university and after graduation, it may also be central to the future of humanity" (p. 124). They acknowledged that higher education institutions need to support student learning through a variety of ways in research and inquiry.

The literature on the RTN abounds with debates over the relation between research and teaching (e.g. Malcolm, 2014; Neumann, 1992; Robertson \& Blackler, 2006; Tight, 2013). However, research is scarce on how undergraduate students view or experience this topic (Buckley, 2011; Healey et al., 2010; Jiang \& Roberts, 2011; Stappenbelt, 2013). Studies on undergraduate students' experiences of research showed that students generally value research and proximity to a research community but, in practice, feel excluded from research activities (Healey et al., 2010; Jenkins et al., 1998; Robertson \& Blackler, 2006; Zamorski, 2002). In addition, Spronken-Smith et al. (2014) found that first-year students have lower levels of awareness of research and fewer opportunities to engage in research compared to senior students. Levy and Petrulis (2012) similarly argued that first-year undergraduate students need a lot of guidance and formative feedback on carrying out inquiry and research.

Within the Omani context, the Oman Academic Accreditation Agency (OAAA) views the RTN as an important criterion underpinning program evaluation. It stated that "there is a systematic and effective approach to developing and maintaining research-teaching linkages within the program, and these linkages make a positive contribution to the design, delivery, and development of the program" (OAAA, 2016, p. 40). Omani higher education institutions need to meet the OAAA's standards in their pursuit of academic accreditation. The purpose of this article was to contribute - within the context of interest in the RTN — to the existing research, by exploring undergraduate students' awareness and experiences of research in a faculty at Sohar University. 


\section{Literature review}

\subsection{The Research-Teaching Nexus}

The definition and nature of the RTN have been debated in the literature (Clark \& Hordosy, 2019; McLinden et al., 2015; Slapcoff \& Harris, 2014; Tight, 2016; Willcoxson et al., 2011). Part of the debate has formed around the question of whether there is a legitimate nexus between research and teaching. As Slapcoff and Harris (2014, p. 70) argued, "many faculty members did not believe in the teaching-research nexus: they opposed the existence of a link between their teaching and research, arguing that no connection was possible at the undergraduate level." They further pointed out that even in an intensive research university some researchers did not see a relationship between quality of research and quality of teaching at the undergraduate level. On the other hand, the argument supporting the existence of the RTN claims that knowledge produced through research forms the basis of teaching materials. In addition, research-active instructors are more likely to teach the latest advances in their field and provide authenticity to their teaching materials (Stappenbelt, 2013).

Given the diversity of perspectives on the nature of the RTN, Wuetherick (2009) defined the term broadly as any aspect of the interplay between the teaching and research roles of universities, at various levels such as faculty, department, or individual academic member. Tight (2016) pointed out that there are intertwined and immediate linkages between the two terms. While research is about the discovery of new knowledge, teaching is concerned with the dissemination of knowledge and skills. With these broad definitions, the RTN manifests in many forms. These are outlined in the following section.

\subsection{Ways of Linking Research and Teaching}

Researchers have proposed several models and frameworks that describe the ways of linking research and teaching, each based on different principles in a variety of disciplines (e.g., Baldwin, 2005; Griffiths, 2004; Healey, 2005; McLinden et al., 2015; Neumann, 1992; Slapcoff \& Harris, 2014; Visser-Wijnveen et al., 2010). Building on Griffiths' work (2004), Healey (2005) suggested a model for curriculum design that involves students more heavily in the RTN. It includes the following approaches (pp. 69-70):

- Research-led: Students learn about current research findings in the discipline. The curriculum is dominated by faculty research interests or others, and information transmission is the main teaching mode.

- Research-oriented: Students learn about research skills and techniques. The curriculum emphasizes the processes by which knowledge is produced.

- Research-based: Students learn as researchers by undertaking research and inquiry. The curriculum is mainly organized around inquiry-based activities.

- Research-tutored: Students engage in group discussions with instructors about research findings. The curriculum emphasizes critical review and discussion of research.

Zimbardi and Myatt (2014) identified five models of undergraduate research activities across a diverse range of disciplines. The models were apprenticeship, industry project, inquiry, methods course, and mixed model (which combines some features of the previous models). It was clear that lecturers in different disciplines combined elements of these models in their undergraduate curriculum.

Based on their analysis of the OAAA's indicators and literature, Paquibut and Al Naamani (2019) identified five main manifestations of the RTN, which include faculty research used in teaching, research by others used in teaching, faculty involving students in his/her research, faculty-guided student research, and research on pedagogy used to improve teaching. This analysis provides Omani higher education institutions with a range of implementation options that are in line with the OAAA's framework.

Going beyond models and approaches to the RTN, several researchers indicated that staff conceptions of research influence their practices of the RTN (Ball \& Mohamed, 2014; Brew, 2001; Jenkins, 2004; Locus et al., 2008). For example, academics in the environmental sciences may view research as the activity of fieldwork, those in the social sciences may view it as the activity of interviewing people, and those in language studies may view it as the process of applying a new idea to a piece of text (Locus et al., 2008).

Given the changing nature and differing conceptions of research, teaching, and learning among instructors and students (Healey, 2005), it is necessary to consider additional factors that affect students' understandings and experiences of the RTN, including the developing interests and experiences of students, emergent employment goals, and the wider context of teaching and learning in higher education institutions (Clark \& Hordosy, 2019). 


\subsection{Students' Perceptions of the RTN}

Giving student voices (e.g., awareness, experiences, and perceptions) a more central role in the RTN is very important. Using international multi-institutional comparison, Turner et al. (2008) surveyed 500 final-year undergraduate students about their awareness, experience, and perceptions of research in four universities in the UK and Canada. Students reported awareness of a wide range of research activities (e.g., research seminars, research outputs, research displays and opportunities). They reported that research experiences were best learned through involvement in their own research projects. Similarly, Healey et al. (2010) surveyed a sample of 194 postgraduate and undergraduate students about their awareness, experiences, and perceptions of research in a UK university. The most recognized sources of awareness were board displays, academic articles and books, research seminars, and research exhibitions. However, many students were not aware of the research in which their teaching staff was engaged. They reported that their awareness and experiences of research increased most when they were involved in undertaking research projects. Students reported a wide range of research experiences, including writing a thesis/dissertation, hearing staff discuss their research within a module, listening to a guest lecturer discuss his/her research, and reading papers/reports by academic staff.

Students who participated in the RTN reported several advantages, including increasing understanding and interest in the course, appreciating instructors' expertise, appreciating research findings, increasing awareness of methodological issues, and developing research-related skills (Healey et al., 2010; Jenkins et al., 1998; Spronken-Smith et al., 2014). One interesting advantage emphasized by Visser-Wijnveen et al. (2012) was that students reported achieving more learning outcomes related to disposition and awareness of research than intended by their instructors. On the other hand, students reported some disadvantages of the RTN, such as the lack of availability of lecturers, the priority of research over teaching by lecturers, and the apparent lack of interest of lecturers in supporting students (Healey et al., 2010; Jenkins et al., 1998).

Most studies on the RTN have been conducted in Europe, North America, Australia, and New Zealand. There is a lack of research on undergraduate students' awareness and experiences of the RTN in the Omani context despite efforts by the OAAA to promote this topic as a necessary criterion for quality teaching in higher education (OAAA, 2016).

\section{Context of the Study}

Sohar University (SU) is the first private university in Oman. It was established in 2001 and has 6536 students enrolled across six faculties. There are 33 programs at the undergraduate and master's levels. An undergraduate degree at SU normally takes four or five years to complete.

SU is located in Sohar City in North Oman. With its modern infrastructures (e.g., international port, international airport, and industrial projects), Sohar City has become an industrial and commercial hub with significant economic, social, and cultural developments. Within this context, SU focuses on building strategic alliances with national and international communities to promote innovation in educational, cultural, and economic sectors (SU, n.d.).

In the 2011 Quality Audit Report (OAAA, 2011), it was recommended that SU develop and implement a consistent approach to formalize and monitor the RTN throughout the university. Since then, there have been significant changes aimed at the enhancement of quality teaching and learning through the RTN. For example, the Strategic Plan (2018-2023) clearly emphasized linkages between research and teaching as one way to promote quality teaching. It further stated that (SU, n.d.):

The University is committed to the increased development of research and knowledge transfer during the coming five years that meets international standards. We believe that higher education and the student experience is enhanced by delivery in an environment where academic staff are engaged with research, innovation and knowledge transfer. Creation of new knowledge allows us to shape our future, and provides opportunities for wealth generation and enhancement of the quality of life. The University will seek to increase the volume and quality of research and knowledge transfer undertaken, and will promote student engagement in active research projects. This will help build our reputation, and support growth and recruitment of high quality academic staff. (p. 5)

In recent years several workshops on the RTN have been conducted for academic staff (e.g., SU, 2018, 2019). SU met all performance standards in the 2020 auditing process conducted by the OAAA, which is aligned with international best practices (OAAA, 2020). 


\section{Method}

\subsection{Participants}

The population of this study comprised 640 undergraduate students (years 1-4) at the Faculty of Education and Arts at SU. For the selection of sample, a stratified representative sampling was used to select participants of the study based on years of study and programs. A sample of 375 undergraduate students was determined to show statistical significance at a 95\% alpha level. Considering low response rate in survey research, 550 undergraduate students were randomly selected from a list of student emails provided by the Registration Office. They were distributed across all programs: Arabic Language and Literature, Physical Education, Mathematics Education, and English Language Education. Of the 550 undergraduate students, 240 students responded to a survey (a response rate of $44 \%)$.

\subsection{Instrument}

An anonymous online survey was used to collect data for the study. Survey items were modified from a survey used by Turner et al. (2008). Some survey items were also modified from the literature (e.g., Casey et al., n.d.). The survey was reviewed by a panel of educators at SU who suggested the addition of some items specific to SU-including awareness of LRC e-resources, research grants, and research awards, which are increasingly available to undergraduate students. An item relating to research assistants was removed from the survey because undergraduate students were unlikely to have occupied this role.

The survey included four sections: demographics, awareness of research, experiences of research, and an open-ended question asking participants to describe a research experience that they had during their study at SU and some advantages and disadvantages of the RTN. It consisted of yes/no questions to determine students' awareness and experiences of research. The internal consistency of the survey was evaluated using Cronbach's alpha. The alpha values were .868 and .897 for awareness and experiences of research respectively. The resulting alpha value for the whole scale was .926.

\subsection{Procedures}

Data were collected in the second semester of the academic year 2019/2020, following approval of the study by SU. Students participated voluntarily in this study and responded anonymously to the survey. Statistical analyses included descriptive statistics such as frequencies and percentages. Chi-squared tests were performed to explore the association between year of study and awareness and experiences of research. The magnitudes of Phi coefficients were interpreted based on Rea and Parker's guidelines (Kotrlik \& Williams, 2003). The open-ended question was analyzed by identifying common themes across students' responses.

\section{Results}

\subsection{Demographics}

Of the 240 participants, $218(90.8 \%)$ were female and $22(9.2 \%)$ were male. Most participants were majoring in Arabic Language and Literature (42.9\%), followed by Physical Education (37.5\%), Math Education (17.9\%), and English Language (1.7\%). The majority of participants $(70 \%)$ were enrolled in the first and second years, with (30\%) in the third and fourth years.

\subsection{Awareness of Research}

As summarized in Table 1, the research activities that students were most aware of at SU were research seminars/conferences (75\%), academic staff/areas with a national and international reputation $(61.7 \%)$, research outputs produced by SU staff (e.g., books and journal articles) (59.2\%), and student research groups (58.8\%). 
Table 1. Number and percentage of students answering "yes" to the question "are you aware of any of the following at the university?"

\begin{tabular}{lcc}
\hline Awareness of research & $\begin{array}{c}\text { Responses } \\
(n=240)\end{array}$ & Percentage \\
\hline Research seminars/conferences & 180 & 75 \\
Research posters/displays & 128 & 53.3 \\
Student research groups & 141 & 58.8 \\
Research awards & 82 & 34.2 \\
Research grants & 63 & 26.2 \\
LRC e-databases & 133 & 55.4 \\
Existence of research units & 100 & 41.7 \\
Existence of research laboratories & 106 & 44.2 \\
Advertisement of postgraduate studies & 124 & 51.7 \\
Advertisement of research opportunities & 89 & 37.1 \\
Research outputs produced by SU staff (e.g., books and journal articles) & 142 & 59.2 \\
Academic staff/areas at SU with a national and international reputation & 148 & 61.7 \\
\hline
\end{tabular}

A chi squared test was used to determine the association between the year of study and awareness of research. As indicated in Table 2, there was a statistically significant association between year of study and awareness of research awards $\left(\chi^{2}(1, n=240)=4.830, p<.05\right.$, phi=.142, weak association), and between year of study and awareness of research grants $(\chi 2(1, n=240)=5.166, p<.05$, phi $=.147$, weak association $)$. 
Table 2. Association between year of study and awareness of research

\begin{tabular}{|c|c|c|c|c|c|c|}
\hline \multirow[b]{2}{*}{ Awareness of research } & \multirow[b]{2}{*}{ Responses } & \multicolumn{2}{|c|}{ Year of study (\%) } & \multirow[b]{2}{*}{$\chi^{2}$} & \multirow[b]{2}{*}{$P$} & \multirow[b]{2}{*}{ Phi } \\
\hline & & $\begin{array}{c}\left(1^{\mathrm{st}} \& 2^{\text {nd }}\right) \\
(n=168)\end{array}$ & $\begin{array}{c}\left(3^{\text {rd }} \& 4^{\text {th })}\right. \\
(n=72)\end{array}$ & & & \\
\hline \multicolumn{7}{|c|}{ Research seminars/conferences } \\
\hline & $\begin{array}{l}\text { Yes } \\
\text { No }\end{array}$ & $\begin{array}{c}68.3 \\
75\end{array}$ & $\begin{array}{c}31.7 \\
25\end{array}$ & .952 & .329 & .063 \\
\hline Research posters/displa & & & & & \multirow[b]{2}{*}{.114} & \multirow[b]{2}{*}{.102} \\
\hline & $\begin{array}{l}\text { Yes } \\
\text { No }\end{array}$ & $\begin{array}{c}65.6 \\
75\end{array}$ & $\begin{array}{c}34.4 \\
25\end{array}$ & 2.500 & & \\
\hline Student research groups & & & & & & \multirow[b]{2}{*}{.124} \\
\hline & $\begin{array}{l}\text { Yes } \\
\text { No }\end{array}$ & $\begin{array}{l}65.2 \\
76.8\end{array}$ & $\begin{array}{l}34.8 \\
23.2\end{array}$ & 3.675 & .055 & \\
\hline Research awards & $\begin{array}{l}\text { Yes } \\
\text { No }\end{array}$ & $\begin{array}{c}61 \\
74.7\end{array}$ & $\begin{array}{c}39 \\
25.3\end{array}$ & 4.830 & $.028 *$ & .142 \\
\hline Research grants & $\begin{array}{l}\text { Yes } \\
\text { No }\end{array}$ & $\begin{array}{c}58.7 \\
74\end{array}$ & $\begin{array}{c}41.3 \\
26\end{array}$ & 5.166 & $.023^{*}$ & .147 \\
\hline LRC e-databases & $\begin{array}{l}\text { Yes } \\
\text { No }\end{array}$ & $\begin{array}{c}69.2 \\
71\end{array}$ & $\begin{array}{c}30.8 \\
29\end{array}$ & .097 & .755 & .020 \\
\hline Existence of research ur & $\begin{array}{l}\text { Yes } \\
\text { No }\end{array}$ & $\begin{array}{c}72 \\
68.6\end{array}$ & $\begin{array}{c}28 \\
31.4\end{array}$ & .327 & .568 & 0.37 \\
\hline Existence of research la & $\begin{array}{c}\text { ratories } \\
\text { Yes } \\
\text { No }\end{array}$ & $\begin{array}{l}70.8 \\
69.4\end{array}$ & $\begin{array}{l}29.2 \\
30.6\end{array}$ & .051 & .820 & .015 \\
\hline Advertisement of postg & $\begin{array}{c}\text { uate studies } \\
\text { Yes } \\
\text { No }\end{array}$ & $\begin{array}{l}66.9 \\
73.3\end{array}$ & $\begin{array}{l}33.1 \\
26.7\end{array}$ & 1.147 & .284 & .069 \\
\hline Advertisement of resear & $\begin{array}{c}\text { opportunitie } \\
\text { Yes } \\
\text { No }\end{array}$ & $\begin{array}{l}66.3 \\
72.2\end{array}$ & $\begin{array}{l}33.7 \\
27.8\end{array}$ & .926 & .336 & .062 \\
\hline Research outputs produ & $\begin{array}{l}\text { by SU staff } \\
\text { Yes } \\
\text { No }\end{array}$ & $\begin{array}{c}\text { g., books an } \\
67.6 \\
73.5\end{array}$ & $\begin{array}{c}\text { ournal artic } \\
32.4 \\
26.5\end{array}$ & .949 & .330 & .063 \\
\hline Academic staff/areas at & $\begin{array}{c}\text { J with a nati } \\
\text { Yes } \\
\text { No }\end{array}$ & $\begin{array}{c}1 \text { and interna } \\
64.9 \\
78.3\end{array}$ & $\begin{array}{c}\text { nal reputati } \\
35.1 \\
21.7\end{array}$ & 4.848 & .028 & .142 \\
\hline
\end{tabular}

${ }^{*} p<0.05$

\subsection{Experiences of Research}

As summarized in Table 3, the top five research experiences were engaging in group work (77.9\%), undertaking an independent research project as part of a course (74.6\%), learning about research values and ethics (69.6\%), being a subject/participant of research conducted by a faculty member (69.6\%), and learning about research methods in your specialty area $(66.2 \%)$. The least-common research experiences were participating in a research competition (22.9\%), engaging in discussions about research findings (23.8\%), and being involved in fieldwork/ practical activities based on a research project $(28.3 \%)$. 
Table 3. Number and percentage of students answering "yes" to the question "have you gained experience of the following during your study at the university?"

\begin{tabular}{lcc}
\hline Experiences of research & $\begin{array}{c}\text { Responses } \\
(n=240)\end{array}$ & Percentage \\
\hline Attending a research seminar/conference & 150 & 62.5
\end{tabular}

Hearing a staff member discuss his/her research work in a course

Undertaking an independent research project as part of a course (e.g., writing an

Reading a research paper/report or book written by academic staff at SU

Engaging in discussions about research findings

Hearing a guest lecturer discuss research in a course

Learning about research methods in your specialty area

Learning about research values and ethics

Contributing to a research paper, report, or other research outputs (e.g., review of skills, and performance skills)

As seen in Table 4, a chi squared test revealed a statistically significant association between year of study and some research experiences, including research seminars/conferences $(\chi 2(1, n=240)=5.418, p<.05$, phi $=.150$, weak association), involvement in fieldwork/practical activities $(\chi 2(1, n=240)=4.256, p<.05$, phi $=.133$, weak association), and reading a research paper/report or book written by academic staff $(\chi 2(1, n=240)=6.717, p<.05$, phi $=.167$, weak association). 
Table 4. Association between year of study and experiences of research

\begin{tabular}{|c|c|c|c|c|c|c|}
\hline \multirow[b]{2}{*}{ Experiences of research } & \multirow[b]{2}{*}{ Responses } & \multicolumn{2}{|c|}{ Year of study $(\%)$} & \multirow[b]{2}{*}{$\chi^{2}$} & \multirow[b]{2}{*}{$P$} & \multirow[b]{2}{*}{ Phi } \\
\hline & & $\begin{array}{c}\left(1^{\text {st }} \& 2^{\text {nd }}\right) \\
(n=168)\end{array}$ & $\begin{array}{c}\left(3^{\mathrm{rd}} \& 4^{\mathrm{th})}\right. \\
(n=72)\end{array}$ & & & \\
\hline \multicolumn{7}{|c|}{ Attending a research seminar/conference } \\
\hline & Yes & 64.7 & 35.3 & \multirow{2}{*}{5.418} & \multirow{2}{*}{$.020 *$} & \multirow{2}{*}{.150} \\
\hline & No & 78.9 & 21.1 & & & \\
\hline \multicolumn{7}{|c|}{ Hearing a staff member discuss his/her research work in a course } \\
\hline & Yes & 66.0 & 34.0 & \multirow{2}{*}{2.660} & \multirow{2}{*}{.103} & \multirow{2}{*}{.105} \\
\hline & No & 75.8 & 24.2 & & & \\
\hline \multicolumn{7}{|c|}{ Undertaking an independent research project as part of a course } \\
\hline & Yes & 67.6 & 32.4 & \multirow{2}{*}{1.935} & \multirow{2}{*}{.164} & \multirow{2}{*}{.090} \\
\hline & No & 77.0 & 23.0 & & & \\
\hline \multicolumn{7}{|c|}{ Being a subject/participant of research conducted by a faculty member } \\
\hline & Yes & 66.3 & 33.7 & 3388 & 066 & 110 \\
\hline & No & 77.9 & 22.1 & 5.500 & .000 & .111 \\
\hline Being involved in fieldw & practical a & ies based on & esearch proj & & & \\
\hline & Yes & 60.3 & 39.7 & 4256 & $.039 *$ & .133 \\
\hline & No & 73.8 & 26.6 & & & \\
\hline Reading a research pape & port or book & ten by acade & c staff at SU & & & \\
\hline & Yes & 59.3 & 40.7 & 6.717 & $.010 *$ & .167 \\
\hline & No & 75.5 & 24.5 & 0.117 & .010 & $.10 \%$ \\
\hline Engaging in discussions & out research & ngs & & & & \\
\hline & Yes & 61.4 & 38.6 & 2.631 & .105 & .105 \\
\hline & No & 72.7 & 27.3 & & & \\
\hline Hearing a guest lecturer & cuss researcl & course & & & & \\
\hline & Yes & 61.8 & 38.2 & 3.525 & .060 & .121 \\
\hline & No & 73.8 & 26.6 & $5 . J 25$ & .000 & \\
\hline Learning about research & thods in you & cialty area & & & & \\
\hline & Yes & 69.2 & 30.8 & .150 & .699 & .025 \\
\hline & No & 71.6 & 28.4 & & & \\
\hline Learning about research & ues and ethi & & & & & \\
\hline & Yes & 67.5 & 32.5 & 1.531 & .216 & .080 \\
\hline & No & 75.3 & 24.7 & 1.531 & .210 & .000 \\
\hline Engaging in inquiry-base & earning & & & & & \\
\hline & Yes & 68.4 & 31.6 & .187 & .666 & .028 \\
\hline & No & 71.0 & 29.0 & & & \\
\hline Engaging in problem-ba & learning & & & & & \\
\hline & Yes & 64.9 & 35.1 & 2.593 & .107 & .104 \\
\hline & No & 74.4 & 25.6 & 2.595 & .107 & .104 \\
\hline Engaging in group work & & & & & & \\
\hline & Yes & 66.8 & 33.2 & 4.014 & $.045^{*}$ & .129 \\
\hline & No & 81.1 & 18.9 & & & \\
\hline Engaging in work-based & rning & & & & & \\
\hline & Yes & 59.2 & 40.8 & 5.647 & $.017 *$ & .153 \\
\hline & No & 74.6 & 25.4 & & & \\
\hline Contributing to a researc & aper, report, & ther research & tputs & & & \\
\hline & Yes & 76.0 & 24.0 & 2.939 & .086 & .111 \\
\hline & No & 65.7 & 34.3 & & & \\
\hline Hearing a lecturer discus & ow research & onduct resea & in your spec & lty area & & \\
\hline & Yes & 68.4 & 31.6 & 354 & 552 & 038 \\
\hline & No & 72.0 & 28.0 & & & \\
\hline Participating in a researc & ompetition & & & & & \\
\hline & Yes & 56.4 & 43.6 & 6.318 & $.012 *$ & .162 \\
\hline & No & 74.1 & 25.9 & & & \\
\hline
\end{tabular}


Table 4. Association between year of study and experiences of research (continued)

\begin{tabular}{|c|c|c|c|c|c|c|}
\hline \multirow[b]{2}{*}{ Experiences of research } & \multirow[b]{2}{*}{ Responses } & \multicolumn{2}{|c|}{ Year of study $(\%)$} & \multirow[b]{2}{*}{$\chi^{2}$} & \multirow[b]{2}{*}{$P$} & \multirow[b]{2}{*}{ Phi } \\
\hline & & $\begin{array}{c}\left(1^{\mathrm{st}} \& 2^{\mathrm{nd}}\right) \\
(n=168)\end{array}$ & $\begin{array}{c}\left(3^{\mathrm{rd}} \& 4^{\mathrm{th})}\right. \\
(n=72)\end{array}$ & & & \\
\hline \multicolumn{7}{|c|}{ Attending an artistic performance or expedition linked to your specialty area } \\
\hline & Yes & 66.3 & 33.7 & 1.144 & .291 & .068 \\
\hline & No & 72.7 & 27.3 & & & \\
\hline \multicolumn{7}{|c|}{$\begin{array}{l}\text { Developing research skills (e.g., fieldwork skills, interviewing, statistical analysis skills, and } \\
\text { performance skills) }\end{array}$} \\
\hline & Yes & 64.1 & 35.9 & 1.914 & .167 & .089 \\
\hline & No & 72.8 & 27.7 & 1.914 & .107 & .00 \\
\hline
\end{tabular}

\subsection{Quality of Research Experiences}

The last part of the survey asked participants to describe a research experience that they have gained and to mention the advantages and disadvantages of their involvement in the RTN. From a total of 240 students, 62 students (25.8\%) responded to this question. They wrote a wide range of interesting responses. In general, their responses tended to be short and included more than one advantage. The perceived advantages of the RTN were grouped into four themes: developing research skills, developing research ethics, gaining new knowledge, and being confident (Table 5).

Table 5. Perceived advantages of the RTN

\begin{tabular}{|c|c|}
\hline Perceived advantages & Example of comments \\
\hline Developing research skills & $\begin{array}{l}\text { In the first year, we completed a group project and learned to conduct } \\
\text { interviews with trainers. We also did playground measurements for our } \\
\text { project (First-year female student, Physical Education). }\end{array}$ \\
\hline Developing research ethics & $\begin{array}{l}\text { In my first year, I had difficulty in writing research assignments. For } \\
\text { example, I had a high similarity level on Turnitin. Then, I learned the } \\
\text { best way to write a research paper (Second-year female student, } \\
\text { Physical Education). }\end{array}$ \\
\hline Gaining new knowledge & $\begin{array}{l}\text { I use this method in a lot of research. It gives me all the answers to my } \\
\text { questions and through it I can reach new and accurate discoveries and } \\
\text { facts (First-year female student, Physical Education). }\end{array}$ \\
\hline Being confident & $\begin{array}{l}\text { In the research that I did during my studies of specialization courses, } \\
\text { there were many positive aspects. For example, the role of research in } \\
\text { enhancing students' confidence, giving eloquence in conversation, and } \\
\text { enabling them to confidently consider different views (Second-year } \\
\text { male student, Arabic Language \& Literature). }\end{array}$ \\
\hline
\end{tabular}

Despite a wide range of advantages mentioned by students, several students reported two common disadvantages. The most obvious disadvantage, mentioned by eight students (13\%), was a perceived lack of hands-on research experience. As one male fourth-year student commented, "I learned how to do research, but without practice." The second disadvantage, identified by two students, was the lack of instructor support, as one female first-year student expressed:

...Because we are new students, we need support, at least in the first semester, to go ahead and produce research in a way that deserves excellent marks. We did research in school, but is school research like university research? No.

\section{Discussion}

The overall findings of the study showed that students were aware of a wide range of research activities-including research seminars/conferences, academic staff/areas with a national and international reputation, research outputs produced by SU staff, and student research groups. However, of some concern was the finding that less than half of the sample were aware of research grants, research awards, and advertisements of research opportunities (Table 1). It 
is important to take measures to raise students' awareness of such aspects of research. It is noteworthy that research grants, research awards, and LRC e-databases are increasingly available for undergraduate students.

Students showed varied research experiences - such as engaging in group work, undertaking independent research projects, learning about research values and ethics, and being a subject/participant of research. This reflects a growing interest in the dissemination of the RTN at SU through professional development workshops. Worryingly, the percentage of students engaging in active learning experiences decreased-including developing research skills, participating in the work-related experience, engaging in discussions of research findings, and participating in fieldwork or practical activities. In light of this finding, SU instructors should focus on providing a wide range of active learning experiences because students are most likely to benefit from the RTN when they are actively engaged in teaching and learning activities (Healey et al., 2010).

The findings of this study supported the findings of previous studies conducted on students' awareness and experiences of research. For example, undergraduate students perceived a number of tangible benefits of the RTN -including gaining knowledge and increased understanding of courses (Healey et al., 2010; Jenkins et al., 1998; Spronken-Smith et al., 2014). They also appeared to have few research experiences of fieldwork/practical activities and little contribution to research outputs (Casey et al., n.d.; Healey et al., 2010; Spronken-Smith et al., 2014; Turner et al., 2008). Surprisingly, unlike the findings of previous studies, $62 \%$ of SU students were aware of areas/people of national and international reputations. It is noteworthy that international academic staff comprises $70 \%$ of the total academic staff at SU (Sohar University, n.d.).

It was clear from the written responses that undergraduate students faced two main challenges arising from their participation in the RTN: a lack of hands-on research experience and a lack of instructor support. It was beyond the scope of the current study to identify the reasons for these challenges. However, several authors pointed to active instructional strategies that enhance the RTN — such as inquiry-based learning, problem-based learning, and fieldwork (e.g., Buckley, 2011; Healey et al., 2010; Pan et al., 2014). In addition, Pan et al. (2014) emphasized the importance of implementing systematic linkages between research and teaching across entire educational programs, to address the progressive nature of learning, interrelated dynamics of the RTN linkages, and their associated stakeholders. This can help to achieve optimal implementation of the RTN.

This study relied on an online survey as the only source of data collection, which took place during the second semester of the academic year 2019/2020 at the time of university campus closure because of the Coronavirus Pandemic. As a result, there was no face-to-face instruction on campus, which could provide students with additional learning experiences on the RTN. As with other studies on students' awareness and experiences of research (e.g., Healey et al., 2010; Spronken-Smith et al., 2014), findings of this study should be treated cautiously because students who represent different programs at the Faculty of Education and Arts might have different conceptions of the term "research".

\section{Conclusion and Recommendations}

The current study provided insights into undergraduate students' awareness and experiences of research. The outcomes of the study showed that while there was good evidence of students' awareness and experiences of research, less than half of the students in the sample were aware of or had experienced important research activities. In addition, the qualitative responses indicated the need for more hands-on research experience and instructor support. It can be concluded from the findings of the study that much effort is needed to enhance students' awareness and experiences of the RTN.

The study pointed to some recommendations that need attention. First, further action should be taken into account to increase students' awareness of research. Second, it is important to engage students in a wide range of research experiences that allow them to apply research skills. Finally, students should be provided with additional academic support, including the explanation of research assignments and an increased amount of time spent by the staff with their students.

Further research that incorporates qualitative and quantitative measures is needed to explore students' awareness and experiences of research. What do undergraduate students perceive as valuable research experiences? What are the barriers to implementing active research experiences? What are the effects of the RTN on undergraduate students' research outputs? Ultimately, these and other questions need to be investigated for a better understanding of students' awareness and experiences of the RTN. 


\section{Acknowledgments}

The author wishes to thank Dr. Dawne Irving-Bell, Edge Hill University, for her constructive comments on an earlier draft of this paper. In addition, special thanks go to students for their participation in this study.

\section{References}

Baldwin, G. (2005). The teaching-research nexus: How research informs and enhances learning and teaching in the University of Melbourne. The University of Melbourne. https://melbournecshe.unimelb.edu.au/_data/assets/pdf_file/0006/1761207/TR_Nexus2005.pdf

Ball, S., \& Mohamed, A., D. M. (2014). Insights on how students perceive the research-teaching nexus: A case study of hospitality management students. Journal of Hospitality, Leisure, Sport and Tourism Education, 9(2), 89-101. https://doi.org/10.3794/johlste.92.222

Brew, A. (2001). Conceptions of research: A phenomenographic study. Studies in Higher Education, 26(3), $271-285$. https://doi.org/10.1080/03075070120076255

Buckley, C. A. (2011). Student and staff perceptions of the research-teaching nexus. Innovations in Education and Teaching International, 48(3), 313-322. https://doi.org/10.1080/14703297.2011.593707

Casey, M., Howell, K., \& Meehan, M. (n.d.). UCD students' awareness and experiences of research in their undergraduate programmes. University College Dublin. https://www.ucd.ie/teaching/t4media/fellows_report_student_perceptions.pdf

Clark, T., \& Hordosy, R. (2019). Undergraduate experiences of the research/ teaching nexus across the whole student lifecycle. Teaching in Higher Education, 24(3), 412-427. https://doi.org/10.1080/13562517.2018.1544123

Griffiths, R. (2004). Knowledge production and the research-teaching nexus: The case of the built environment disciplines. Studies in Higher Education, 29(6), 709-726. https://doi.org/10.1080/0307507042000287212

Healey, M. (2005). Linking research and teaching exploring disciplinary spaces and the role of inquiry based learning. In R. Barnett. (Ed.), Reshaping the university: New relationships between research, scholarship and teaching (pp. 67-78). McGraw-Hill/Open University Press.

Healey, M., \& Jenkins, A. (2009). Developing undergraduate research and inquiry. The Higher Education Academy.

Healey, M., Jordan, F., Pell. B., \& Short, C. (2010). The research-teaching nexus: A case study of students' awareness, experiences and perceptions of research. Innovations in Education and Teaching International, 47(2), 235-246. https://doi.org/10.1080/14703291003718968

Jenkins, A. (2004). A guide to the research evidence on teaching-research relations. The Higher Education Academy.

Jenkins, A., Blackman, T., Lindsay, R., \& Paton-Saltzberg, R. (1998). Teaching and research: Student perspectives and policy implications. Studies in Higher Education, 23(2), 127-141. https://doi.org/10.1080/03075079812331380344

Jiang, F., \& Roberts, P. J. (2011). An investigation of the impact of research-led education on student learning and understandings of research. Journal of University Teaching \& Learning Practice, 8(2), 1-14. https://ro.uow.edu.au/jutlp/vol8/iss2/4

Kotrlik, J. W., \& Williams, H. A. (2003). The incorporation of effect size in information technology, learning, and performance research. Information Technology, Learning, and Performance Journal, 21(1), 1-7.

Levy, P., \& Petrulis, R. (2012). How do first-year university students experience inquiry and research, and what are the implications for the practice of inquiry-based learning? Studies in Higher Education, 37(1), 85-101. https://doi.org/10.1080/03075079.2010.499166

Locus, L., Healey, M., Jenkins, A., \& Short, C. (2008). Academics' experiences and perceptions of 'research' and 'teaching': Developing the relationship between these activities to enhance student learning within different disciplines and institutions. The Higher Education Academy.

Malcolm, M. (2014). A critical evaluation of recent progress in understanding the role of the research-teaching link in higher education. Higher Education, 67(3), 289-301. DOI. 10.1007/s10734-013-9650-8 
McLinden, M., Edwards, C., Garfield, j., \& Moron-Garcia, S. (2015). Strengthening the links between research and teaching: Cultivating student expectations of research-informed teaching approaches. Education in Practice, 2(1), 24-29.

Neumann, R. (1992). Perceptions of the teaching-research nexus: A framework for analysis. Higher Education, 23(2), 159-171. https://doi.org/10.1007/BF00143643

Oman Academic Accreditation Authority. (2011). Report of an audit of Sohar University. Author. http://www.oaaa.gov.om/Review/su_audit_report_finalweb.pdf

Oman Academic Accreditation Authority. (2016). Program accreditation manual. Author. http://www.oaaa.gov.om/ProgramPdf/PSAM\%20draft\%20v1\%20for\%20circulation_28\%20March\%202016.pd $\mathrm{f}$

Oman Academic Accreditation Authority. (2020, March 19.). OAAA accredits Sohar University. http://www.oaaa.gov.om/General.aspx\#WhatsNewDetails\&id=674

Pan, W., Cotton, D., \& Murray, P. (2014). Linking research and teaching: Context, conflict and complementarity. Innovations in Education and Teaching International, 51(1), 3-14. https://doi.org/10.1080/14703297.2013.847794

Paquibut, R., \& Al Naamani, A. (2019). Managing organizational change to meet the research-teaching nexus standard: The case of an HEI in the Sultanate of Oman. International Journal of Educational Management, 34(4), 782-793. https://doi.org/10.1108/IJEM-07-2019-0225

Robertson, J., \& Blackler, G. (2006). Students' experiences of learning in a research environment. Higher Education Research \& Development, 25(3), 215-229. https://doi.org/10.1080/07294360600792889

Slapcoff, M., \& Harris, D. (2014). The Inquiry network: A model for promoting the teaching-research nexus in higher education. Canadian Journal of Higher Education, 44(2), 68-84. https://doi.org/10.47678/cjhe.v44i2.183763

Sohar University. (n.d). Strategic plan 2018-2023. Author. https://www.su.edu.om/doc/strategic\%20plan-English.pdf

Sohar University. (2018). Research development: Schedule of activities. Author. http://www.su.edu.om/pdf/workshopres/2018-S1-Workshop\%20Schedule.pdf

Sohar University. (2019). Research development: Schedule of activities. Author. http://www.su.edu.om/pdf/workshopres/2019-S1-Workshop\%20Schedule.pdf

Spronken-Smith, R., Mirosa, R., \& Darrou, M. (2014). 'Learning is an endless journey for anyone': Undergraduate awareness, experiences and perceptions of the research culture in a research-intensive university. Higher Education Research \& Development, 33(2), 355-371. https://doi.org/10.1080/07294360.2013.832169

Stappenbelt, B. (2013). The effectiveness of the teaching-research nexus in facilitating student learning. Engineering Education, 8(1), 111-121. https://doi.org/10.11120/ened.2013.00002

Tight, M. (2016). Examining the research/teaching nexus. European Journal of Higher Education, 6(4), $293-311$. https://doi.org/10.1080/21568235.2016.1224674

Turner, N., Wuetherick, B., \& Healey, M. (2008). International perspectives on student awareness, experiences and perceptions of research: Implications for academic developers in implementing research-based teaching and learning. International Journal for Academic Development, 13(3), $199-211$. https://doi.org/10.1080/13601440802242333

Visser-Wijnveen, G. Van Driel, J. H., Van der Rijst, R. M., Verloop, N., \& Visser, A. (2010). The ideal research-teaching nexus in the eyes of academics: Building profiles. Higher Education Research \& Development, 29(2), 195-210. https://doi.org/10.1080/07294360903532016

Visser-Wijnveen, G. J., van Driel, J. H., van der Rijst, R. M., Visser, A., \& Verloop, N. (2012). Relating academics' ways of integrating research and teaching to their students' perceptions. Studies in Higher Education, 37(2), 219-234. https://doi.org/10.1080/03075079.2010.536913

Willcoxson, L., Manning, M. L., Johnston, N., \& Gethin, K. (2011). Enhancing the research-teaching nexus: Building teaching-based research from research-based teaching. International Journal of Teaching and Learning in Higher Education, 23(1), 1-10. 
Wuetherick, B. (2009). Unpacking the teaching-research nexus and its influence on academic practice. Academic Matters.

https://academicmatters.ca/unpacking-the-teaching-research-nexus-and-itsinfluence-on-academic-practice/

Zamorski, B. (2002). Research-led teaching and learning in higher education: A case. Teaching in Higher Education, 7(4), 411-427. https://doi.org/10.1080/135625102760553919

Zimbardi, K. \& Myatt, P. (2014). Embedding undergraduate research experiences within the curriculum: A cross-disciplinary study of the key characteristics guiding implementation. Studies in Higher Education, 39(2), 233-250. https://doi.org/10.1080/03075079.2011.651448

\section{Copyrights}

Copyright for this article is retained by the author(s), with first publication rights granted to the journal.

This is an open-access article distributed under the terms and conditions of the Creative Commons Attribution license (http://creativecommons.org/licenses/by/4.0/). 